DOI: https://doi.org/10.24297/jaa.v10i0.8119

\title{
Impatiens 'New Guinea' (Impatiens Hawkeri Bull) Hormonal Effects During The Post-Transplant Biomass Accumulation
}

\author{
Jorge Molinari', Pablo Fujinuma ${ }^{1}$; Alberto Pagani'; Marcela Buyatti²; Ernesto Giardina', Adalberto Di \\ Benedetto ${ }^{1-3^{*}}$ \\ dibenede@agro.uba.ar
}

\begin{abstract}
${ }^{1}$ Faculty of Agronomy, University of Buenos Aires, San Martín Avenue 4453 (C1417DSE), Buenos Aires, Argentina.
${ }^{2}$ Faculty of Agricultural Sciences, National University of Litoral, Kreder 2805 (3080), Esperanza, Province of Santa Fe, Argentina.
\end{abstract}

${ }^{3}$ Faculty of Agricultural Sciences, National University of Mar del Plata, Route 226, km. 73.5 (B7620ZAA), Balcarce, Province of Buenos Aires, Argentina.

\begin{abstract}
Pot ornamental plant productivity is related to the environmental growth facilities but negatively affected by the pot root restriction syndrome so during nursery as the post-transplant stage. The physiological mechanism involved included both the synthesis and translocation of auxins and cytokinins. However, clear sink-source and dose-response relationships of exogenous plant regulators such as indole acetic acid (AIA) and benzyl amino purine (BAP) and environment on biomass accumulation in most ornamental foliage plants, including New Guinea Impatiens (Impatiens hawkeri) are lacking. The aim of this work was to analyze the effects of an exogenously shoot-applied auxin and a cytokinin, separately or successively, on the post-transplant biomass accumulation of $I$. hawkeri through the anatomical, morphological and physiological changes observed. Two experiments were performed. The first experiment included the response to only BAP-sprayed plants $(0,5,50$, or $\left.100 \mathrm{mg} \mathrm{L}^{-1}\right)$. For the second experiment, rooting cuttings of $I$. hawkeri were sprayed with different concentrations of IAA $\left(0,5,50\right.$, or $\left.100 \mathrm{mg} \mathrm{L}^{-1}\right)$ followed by different BAP concentrations $\left(0,5,50\right.$, or $\left.100 \mathrm{mg} \mathrm{L}^{-1}\right)$ one week later to run-off at sunset. Results showed that (a) a single BAP or AIA dose increased increase posttransplant biomass accumulation through a higher leaf area expansion and photo assimilate production, (b) as a result of both AIA and BAP spray, the higher NAR the higher post-transplant biomass accumulation, (c) leaf anatomical changes (leaf thickness, intercellular spaces) let a higher carbon dioxide diffusion and fixation with a correlative increase in photo assimilates, (d) a higher root system would be related to a higher cytokinin synthesis. In summary, similarities between responses to either hormone, together with the lack of any IAA BAP interaction, provide two independent routes for commercial growers to increase the productivity of $I$. hawkeri ornamental plants by using early foliar sprays.
\end{abstract}

Keywords: auxins, cytokinins, growth, ornamentals

\section{Introduction}

Impatiens hawkeri hybrids usually known as New Guinea Impatiens are the result of hybridization between three Impatiens species from that country (Tabak and von Wettberg, 2008). New Guinea Impatiens are a vegetativepropagated cultivar grown as annual ornamental. Much of the popularity of New Guinea Impatiens is due to large flower size, wide range of flower colors, and the dark green foliage (Strefeler and Quené, 1985). Flowers appear at the axillar stems, for which a higher leaf appearance rate and ramified stems are required for high commercial acceptance. Additionally, both growth and flowers lifespan are related to available photo assimilates (López and Runkle, 2008; Currey and Lopez, 2015). 
Vegetative-propagated herbaceous bedding plants, such as I. hawkeri, are produced in two distinct phases: a young plant stage, in which shoot tip cutting is rooted, and a finish plant stage, in which the rooted young plant is transplanted into a bigger pot where they are grown until they become marketable (Hutchinson et al., 2012). This implies that plants needs to develop a new root system with stored reserves consumption (Klopotek et al., 2016). The physiological mechanism involved included both the synthesis and translocation of auxins and cytokinins.

Auxins are synthesized in the shoot apical meristem and move through phloem (Bishop et al., 2011). After detachment from the donor plant, phloem basipetal transport of auxins from mature leaves contributes to auxin accumulation in the stem base (Garrido et al., 2003). Because high concentrations of free auxin during the induction phase of adventitious rooting are needed (Han et al., 2009), the exogenous rise of auxin levels in the basal stem likely contributes to the early events of adventitious root formation (Ahakami et al., 2009). Because cytokinins are mainly synthesized in the roots, there is a close relationship between root growth in general, the number of root meristems and cytokinin production in the root system (Aloni et al., 2005). Antagonic (Muraro et al., 2013) or complementary responses between auxins and cytokinins were found. However, the plant response to different indole acetic acid (IAA) and 6, benzyl amino purine (BAP) concentration sprays have been only recently explored (Di Benedetto et al., 2015b; Molinari et al., 2018), for which the post-transplant response of most ornamental pot plant included Impatiens 'New Guinea' (Impatiens hawkeri Bull) are lacking.

The aims of this work were to analyze the effects of an exogenously shoot-applied auxin and a cytokinin, separately or successively, on the post-transplant biomass accumulation of I. hawker through the anatomical, morphological and physiological changes observed.

\section{Materials and Methods}

\section{Plant Material and Treatments}

To reach the proposed objectives and validate proposed hypothesis, two experiments were conducted under a greenhouse located at the Faculty of Agronomy campus, University of Buenos Aires, Argentina (34 $35^{\prime} 59^{\prime \prime}$, $58^{\circ} 22^{\prime} 23^{\prime \prime} \mathrm{W}$ ) from October $15^{\text {th }} 2013$ to February 20 th 2014 (experiment 1) and from October $11^{\text {th }} 2014$ to February $10^{\text {th }} 2015$ respectively.

For both experiments, stem cuttings (30 per treatment) of Impatiens 'Nueva Guinea' (Impatiens hawkeri Bull) from 128 plug cell trays $\left(17.37 \mathrm{~cm}^{3} \mathrm{cell}^{-1}\right)$ were transplanted into $1.200 \mathrm{~cm}^{3}$ plastic pots (one cutting per pot) filled with a 2:2:1 (v/v) mix of Sphagnum maguellanicum peat, river waste and perlite. Plants were watered daily and fertilized weekly with $\mathrm{N}, \mathrm{P}, \mathrm{K}$ and Ca fertilizer added to the irrigation water (150 $\left.\mathrm{mg}^{-1} \mathrm{~N}\right)$ (2:1:2:2 N:P:K:Ca).

For experiment 1 , seven days after transplantation, all leaves were sprayed to run-off at sunset with different concentrations of $\operatorname{BAP}\left(0,5,50\right.$, or $\left.100 \mathrm{mg} \mathrm{L}^{-1}\right)$. On the other hand, for experiment 2, seven days after transplantation, all leaves were sprayed to run-off at sunset with different concentrations of $\operatorname{BAP}(0,5,50$, or 100 $\left.\mathrm{mg} \mathrm{L}^{-1}\right)$ or IAA $\left(0,5\right.$, 50, or $100 \mathrm{mg} \mathrm{L}^{-1}$; Sigma-Aldrich Co., St. Louis, MO, USA), or 16 combinations of the same IAA concentrations followed by the same BAP concentrations 7 days later. The IAA and BAP were first diluted in $80 \%(\mathrm{v} / \mathrm{v})$ ethanol and no surfactants were used.

Daily mean temperatures ( 19.73 to $24.90^{\circ} \mathrm{C}$ and 21.82 to $26.8^{\circ} \mathrm{C}$ for experiment 1 and 2 respectively) and daily

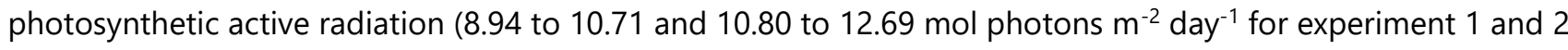
respectively) were recorded with a HOBO sensor (H08-004-02) (Onset Computer Corporation, MA, USA) connected to $\mathrm{HOBO} \mathrm{H} 8$ data logger. The plants were arranged at a density of 25 plants $\mathrm{m}^{-2}$ which avoided mutual shading. 


\section{Assessed Variables}

At $0,60,90$, and 120 days after transplanting, five plants treated with each combination of hormones were destructively sampled in each block. The number of leaves on each plant was recorded, and each leaf area was determined using the ImageJ ${ }^{\circledR}$ (Image Processing and Analysis in Java) software.

The Fresh weights $\left(\mathrm{FW}_{\mathrm{s}}\right)$ of the roots, leaf blades and stems on each plant were determined. Dry weights (DWs) were obtained after drying to constant weight at $80^{\circ} \mathrm{C}$ for 96 hours. The relative rate of leaf area expansion (RLAE) was calculated as the slope of the regression of the natural logarithm $(l n)$ of total leaf area versus time (in days). The rate of leaf appearance (RLA) was calculated as the slope of the number of visible leaves versus time (in weeks). The relative growth rate (RGR) was calculated as the slope of the regression of the natural logarithm of whole plant DW versus time (in days). The mean net carbon assimilation rate (NAR) and leaf area ratio (LAR) as following:

$$
\begin{gathered}
N A R=\frac{k_{w} W_{0} e^{k_{w} t}}{A_{0} e^{k_{a} t}} \\
L A R=\frac{k_{w}}{N A R}
\end{gathered}
$$

where, $\mathrm{k}_{\mathrm{w}}$ : RGR ( $\mathrm{g} \mathrm{g}^{-1}$ days $\left.^{-1}\right) ; \mathrm{W}_{0}$ : extrapolated value of total dry weight at time zero (g); $\mathrm{A}_{0}$ : extrapolated value of external stem area at time zero $\left(\mathrm{cm}^{2}\right) ; \mathrm{k}_{\mathrm{a}}$ : $\operatorname{RLAE}\left(\mathrm{cm}^{2} \mathrm{~cm}^{-2}\right.$ days $\left.{ }^{-1}\right) ; \mathrm{t}$ : time (in days) at the midpoint of the experimental period and e: base of natural logarithms.

The allometric coefficients between root and stems were calculated as the slope $(\boldsymbol{\beta})$ of the straight-line regression of the natural logarithm of the root DW versus the natural logarithm of the stem DW.

Samples of young, fully-expanded leaves were collected to examine leaf anatomy (i.e., overall leaf thickness, the thicknesses of the mesophyll layer and the epidermal layer, and the volume of intercellular spaces) on the final harvest date of experiment 2 (120 days from transplanting). Tissue from the middle region of the lamina was fixed in a mixture of $70 \%(\mathrm{v} / \mathrm{v})$ ethanol, $5 \%(\mathrm{v} / \mathrm{v})$ formalin, $5 \%(\mathrm{v} / \mathrm{v})$ glacial acetic acid, and $20 \%(\mathrm{v} / \mathrm{v})$ distilled water prior to dehydration in an ethanol and tert-butyl alcohol series. Samples were sectioned at $10-20 \mu \mathrm{m}$ thick with a rotary microtome and stained with safranin-crystal violet-fast green. Data presented are the means of three leaves per treatment using ten leaf cross-sections per leaf. Quantitative anatomical data were obtained using Image Pro Express version 6.0 (Media Cybernetics, MD, USA).

\section{Experimental Design and Statistical Analysis}

The experimental design was a completely aleatory design for experiment 1 . The experiment was arranged in a 16-way factorial design, with four concentrations of IAA and four concentrations of BAP. Data were subjected to two-way analysis of variance (ANOVA). STATISTICA 8 (StatSoft, 2013) software was used and the assumptions of ANOVA were checked. Least significant differences (LSD) values were calculated. Slopes from straight-line regressions of RLAE, RGR, NAR, and LAR values were tested using the SMATR package (Warton et al., 2012).

\section{RESULTS}

\section{Experiment 1. BAP response}

\section{Fresh weight accumulation}

At the end of the experiments (120 days from transplant), all BAP-sprayed plants showed significant increase in total fresh weight related to control plants (Fig. 1). 


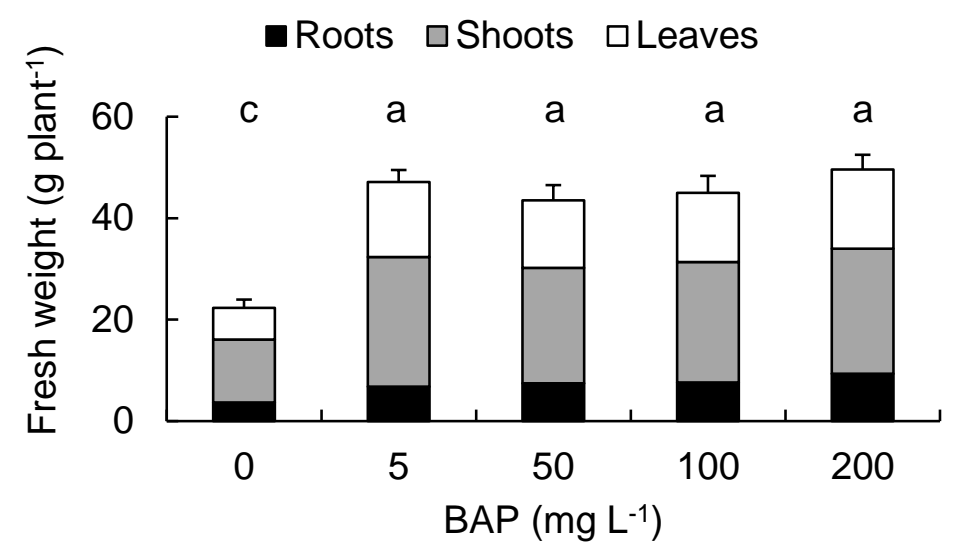

Fig. 1: Fresh weight at the end of the experiment 1 in different plant organs of $I$. hawkeri sprayed with different BAP concentrations. The standard errors over each bar have been indicated. Different lower-case letters indicate significant differences $(P<.05)$ between BAP-sprayed plants.

\section{Leaf area expansion}

Control plants showed the lower both total and individual leaf area as the result of lower RLAE and RLA. A single BAP spray significantly increased all these growth parameters, although the higher response was found in 100 and $200 \mathrm{mg} \mathrm{L}^{-1}$ BAP sprayed-plants (Table 1).

Table 1: Changes in total and individual leaf area at the end of the experiment 1 , in the relative leaf area expansion rate (RLAE) and the rate of leaf appearance (RLA) of $l$. hawkeri plants sprayed with different BAP concentrations $\left(0,5,50,100\right.$ or $\left.200 \mathrm{mg} \mathrm{L}^{-1}\right)$. The probability of the slope being zero was $P \leq 0.001$ for RLAE and RLA. Different lower case letters indicate significant differences $(P \leq 0.05)$ between control and BAP-sprayed plants.

\begin{tabular}{|c|c|c|c|c|}
\hline $\begin{array}{c}\text { BAP } \\
\left(\mathrm{mg} \mathrm{L}^{-1}\right)\end{array}$ & $\begin{array}{c}\text { Leaf area } \\
\left(\mathrm{cm}^{2} \text { plant }^{-1}\right)\end{array}$ & $\begin{array}{l}\text { Leaf area } \\
\left(\mathrm{cm}^{2} \text { leaf }^{-1}\right)\end{array}$ & $\begin{array}{c}\text { RLAE } \\
\left(\mathrm{cm}^{2} \mathrm{~cm}^{-2} \mathrm{day}^{-1}\right)\end{array}$ & $\begin{array}{c}\text { RLA } \\
\left(\text { leaves day }{ }^{-1} \text { plant }^{-1}\right)\end{array}$ \\
\hline 0 & $140.68 \mathrm{c}$ & $11.92 \mathrm{c}$ & $0.0056 \mathrm{c}$ & $0.0605 \mathrm{~d}$ \\
\hline 5 & $277.59 \mathrm{~b}$ & $15.59 \mathrm{~b}$ & $0.0109 \mathrm{~b}$ & $0.1055 \mathrm{c}$ \\
\hline 50 & 309.84 b & $15.79 \mathrm{~b}$ & $0.0117 b$ & $0.1111 \mathrm{c}$ \\
\hline 100 & 334.72 a & $16.70 \mathrm{a}$ & $0.0126 a$ & $0.1279 \mathrm{~b}$ \\
\hline 200 & $354.47 \mathrm{a}$ & $16.85 \mathrm{a}$ & $0.0129 a$ & $0.1491 \mathrm{a}$ \\
\hline
\end{tabular}

\section{Dry weight accumulation and partitioning}

A single BAP spray significantly increased RGR and NAR. The higher response was found in $200 \mathrm{mg} \mathrm{L}^{-1}$ BAP sprayed- plants. A similar response from LAR was found as well. The allometric analysis between roots and stems showed a higher photo assimilates partitioning to roots in control plants and a change towards stems in BAPsprayed plants (Table 2). 
Table 2: Changes in the relative growth rate (RGR), the net assimilation rate (NAR), the leaf area ratio (LAR) and the allometric relationships between roots and stems from I. hawkeri plants sprayed with different BAP concentrations $\left(0,5,50,100\right.$ or $\left.200 \mathrm{mg} \mathrm{L}^{-1}\right)$. The slope straight-line $(\beta)$ is indicated. The probability of the slope being zero was $P \leq 0.001$ for all growth parameters. Different lower case letters indicate significant differences $(P \leq 0.05)$ between control and BAP-sprayed plants.

\begin{tabular}{ccccc}
\hline $\begin{array}{c}\text { BAP } \\
\left(\mathrm{mg} \mathrm{L}^{-1}\right)\end{array}$ & $\begin{array}{c}\text { RGR } \\
\left(\mathrm{g} \mathrm{g}^{-1} \mathrm{day}^{-1}\right)\end{array}$ & $\begin{array}{c}\text { NAR } \\
\left(\mathrm{g} \mathrm{cm}^{2} \mathrm{day}^{-1}\right)\end{array}$ & $\begin{array}{c}\text { LAR } \\
\left(\mathrm{cm}^{2} \mathrm{~g}\right)\end{array}$ & $\beta$ \\
\hline 0 & $0.0081 \mathrm{~d}$ & $6.69 \mathrm{~d}$ & $83.69 \mathrm{c}$ & $2.297 \mathrm{a}$ \\
5 & $0.0114 \mathrm{c}$ & $7.11 \mathrm{c}$ & $160.34 \mathrm{a}$ & $2.017 \mathrm{~b}$ \\
50 & $0.0129 \mathrm{~b}$ & $8.26 \mathrm{~b}$ & $156.17 \mathrm{a}$ & $1.965 \mathrm{c}$ \\
100 & $0.0141 \mathrm{~b}$ & $8.50 \mathrm{~b}$ & $165.88 \mathrm{a}$ & $1.951 \mathrm{c}$ \\
200 & $0.0142 \mathrm{a}$ & $9.70 \mathrm{a}$ & $146.39 \mathrm{~b}$ & $1.930 \mathrm{c}$ \\
\hline
\end{tabular}

\section{Growth parameters relationships}

Positive relationships between RLAE (Fig. 2A), RLA (Fig. 2B), RGR (Fig. 2C), NAR (Fig. 2D) and root DW ( $r^{2}=0.985$, $0.824,0.914$ and 0.844 respectively) were found at the end of the experiment. The lower values belonged to control plants always. On the other hand, an inverse response between the $\beta$ coefficient and root DW $\left(r^{2}=0.873\right)$ (Fig. 2E) with the higher value in control plants was found.

A

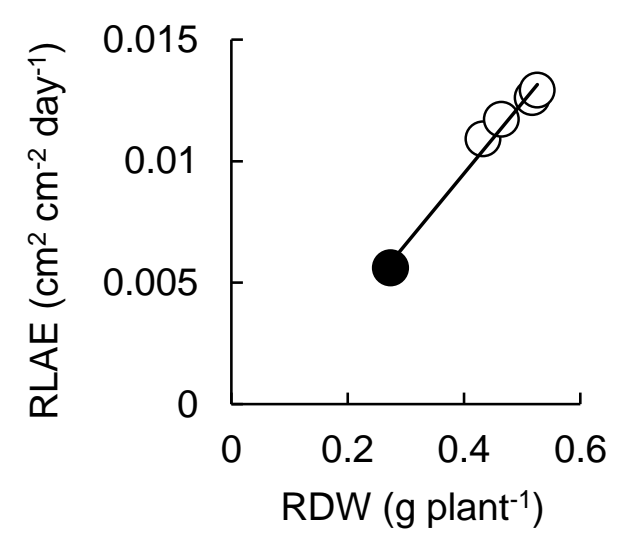

B

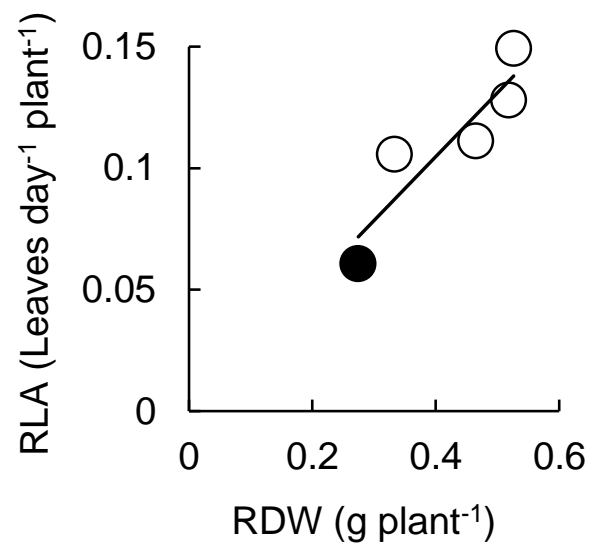


C

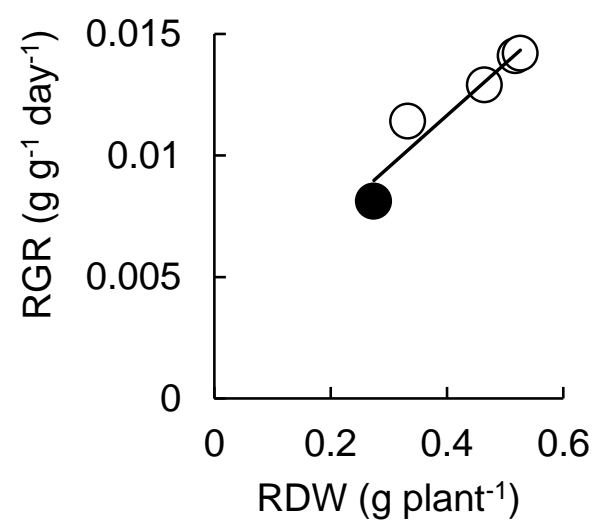

D

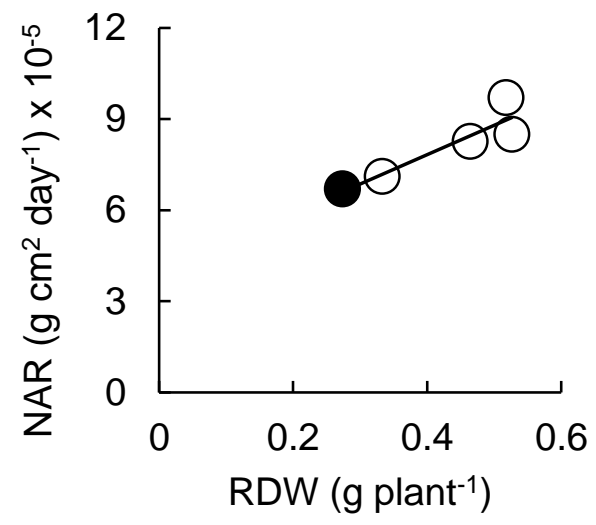

$E$

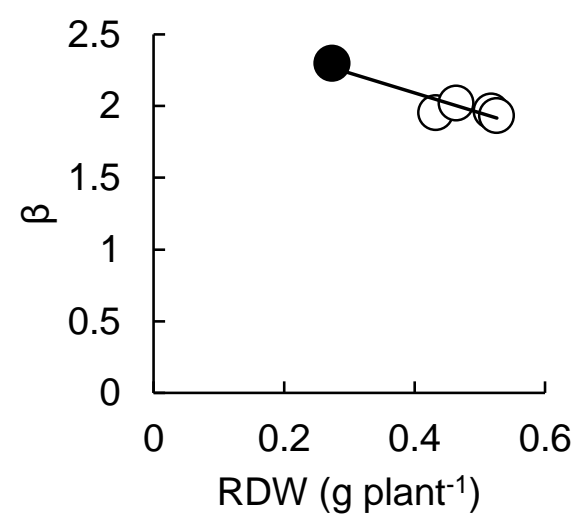

Fig. 2: The relative leaf area expansion rate (RLAE) (A), the rate of leaf appearance (RLA) (B), the relative growth rate (RGR) $(C)$, the net assimilation rate $(D)$ and the partition coefficient $\beta$ (E) related to the relative root DW (RDW). The straight-line regressions were RLAE $=0.029$ RDW $-0.002\left(r^{2}=0.985 ; P \leq 0.001\right), R L A=0.263$ RDW $0.0004\left(r^{2}=0.824 ; P \leq 0.001\right), R G R=0.021 R D W-0.003\left(r^{2}=0.914 ; P \leq 0.001\right), N A R=9.671 \times 10^{-5} R D W+3.96$ $\left(r^{2}=0.844 ; P \leq 0.001\right), \beta=-1.319 R D W+2.65\left(r^{2}=0.873 ; P \leq 0.001\right)$.

\section{Experiment 2. IAA-BAP treatments}

\section{Fresh weight accumulation}

A single application of IAA or BAP at $50 \mathrm{mg} \mathrm{L}^{-1}$ led to a significant increase in total FW accumulation observed 90 days after treatment (Fig. 3A) compared with control plants. In plants treated with IAA and, 7 days later with BAP, addition of the second hormone resulted in only a slight growth promoting effect (generally less than 20\%), which tended to be lower with increasing IAA and BAP concentrations (Fig. 3B). 
A

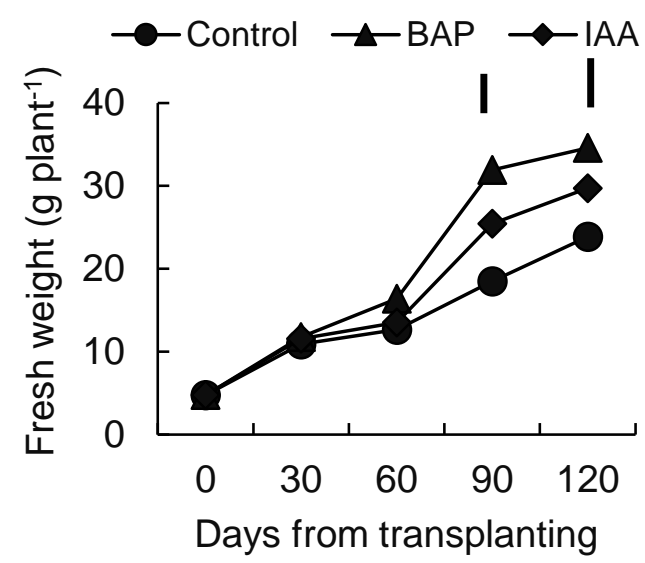

B

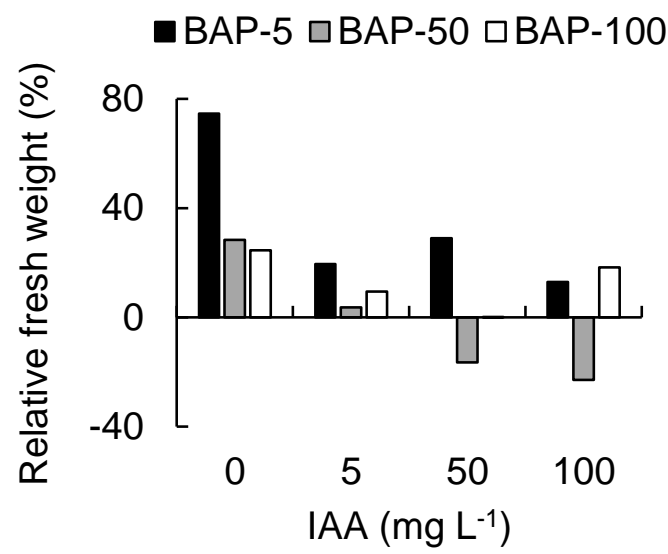

Fig. 3: Total fresh weights (A) in I. hawkeri during the 120 days experiment on control plants and in plants which showed the greatest response to $100 \mathrm{mg} \mathrm{L}^{-1}$ sprays of IAA or BAP applied as a single hormone spray. Panels $B$ shows the effect of a 5,50, or $100 \mathrm{mg} \mathrm{L}^{-1}$ BAP spray application on total fresh weight in plants sprayed 7 days before with IAA at $0,5,50$ or $100 \mathrm{mg} \mathrm{L}^{-1}$. Data are expressed as the percentage change observed following BAP application of 5, 50 or $100 \mathrm{mg} \mathrm{L}^{-1}$ relative to plants sprayed with $0 \mathrm{mg} \mathrm{L}^{-1}$ BAP. Vertical lines indicate least significant differences (LSD).

\section{Leaf area expansion}

Total leaf area and RLAE at final harvest were higher in plants sprayed with either IAA or BAP than in the controls. These were the result of a larger mean values of individual leaf areas and higher RLA. The response to either hormone was similar (Table 3).

At the end of the experimental period, sequential applications of IAA and BAP resulted in an increase in both total and individual leaf area, RLAE and RLA values over the controls which was dependent on the concentrations applied. In plants treated with IAA and, 7 days later with BAP, addition of the second hormone resulted in only a slight growth promoting effect (generally less than 20\%) for leaf areas (Figs. 4A and B) and RLAE (Fig. 4C), which tended to be lower with increasing IAA and BAP concentrations. However, RLA showed a strong response when $50 \mathrm{mg} \mathrm{L}^{-1}$ IAA where BAP sprayed (Fig. 4D).

Table 3: Changes in total and individual leaf area at the end of the experiment 2, in the relative leaf area expansion rate (RLAE) and the rate of leaf appearance (RLA) of I. hawkeri plants sprayed with different IAA-BAP combinations. The probability of the slope being zero was $P \leq 0.001$ for RLAE and RLA. Different lower case letters indicate significant differences $(P \leq 0.05)$ between control and IAA-BAP sprayed plants.

\begin{tabular}{|c|c|c|c|c|}
\hline $\begin{array}{l}\text { IAA-BAP } \\
\left(\mathrm{mg} \mathrm{L}^{-1}\right)\end{array}$ & $\begin{array}{l}\text { Leaf area } \\
\left(\mathrm{cm}^{2} \text { plant }^{-1}\right)\end{array}$ & $\begin{array}{l}\text { Leaf area } \\
\left(\mathrm{cm}^{2} \text { leaf }^{-1}\right)\end{array}$ & $\begin{array}{c}\text { RLAE } \\
\left(\mathrm{cm}^{2} \mathrm{~cm}^{-2} \mathrm{day}^{-1}\right)\end{array}$ & $\begin{array}{c}\text { RLA } \\
\left(\text { (leaves day }^{-1} \text { ) }\right.\end{array}$ \\
\hline $0-0$ & $310.88 \mathrm{~b}$ & $14.96 \mathrm{c}$ & $0.0080 \mathrm{c}$ & $0.1242 \mathrm{~d}$ \\
\hline $0-5$ & $371.13 a$ & $14.57 \mathrm{c}$ & $0.0102 b$ & $0.1605 \mathrm{~b}$ \\
\hline $0-50$ & $311.44 b$ & $16.93 \mathrm{a}$ & $0.0092 \mathrm{c}$ & $0.1220 \mathrm{~d}$ \\
\hline $0-100$ & $373.84 \mathrm{a}$ & $17.40 \mathrm{a}$ & $0.0102 \mathrm{~b}$ & $0.1420 \mathrm{c}$ \\
\hline
\end{tabular}




\begin{tabular}{lllll}
$5-0$ & $330.84 \mathrm{a}$ & $15.59 \mathrm{~b}$ & $0.0086 \mathrm{c}$ & $0.1236 \mathrm{~d}$ \\
$5-5$ & $428.27 \mathrm{a}$ & $17.76 \mathrm{a}$ & $0.0118 \mathrm{a}$ & $0.1563 \mathrm{~b}$ \\
$5-50$ & $436.19 \mathrm{a}$ & $16.89 \mathrm{~b}$ & $0.0124 \mathrm{a}$ & $0.1943 \mathrm{a}$ \\
$5-100$ & $345.39 \mathrm{a}$ & $15.16 \mathrm{~b}$ & $0.0099 \mathrm{~b}$ & $0.1457 \mathrm{c}$ \\
$50-0$ & $364.34 \mathrm{a}$ & $15.28 \mathrm{~b}$ & $0.0104 \mathrm{~b}$ & $0.1857 \mathrm{a}$ \\
$50-5$ & $411.58 \mathrm{a}$ & $16.02 \mathrm{~b}$ & $0.0116 \mathrm{a}$ & $0.1815 \mathrm{a}$ \\
$50-50$ & $313.14 \mathrm{~b}$ & $13.82 \mathrm{c}$ & $0.0086 \mathrm{c}$ & $0.1599 \mathrm{~b}$ \\
$50-100$ & $286.55 \mathrm{~b}$ & $15.13 \mathrm{~b}$ & $0.0072 \mathrm{c}$ & $0.1671 \mathrm{~b}$ \\
$100-0$ & $317.38 \mathrm{~b}$ & $18.44 \mathrm{a}$ & $0.0084 \mathrm{c}$ & $0.1413 \mathrm{c}$ \\
$100-5$ & $381.31 \mathrm{a}$ & $18.12 \mathrm{a}$ & $0.0104 \mathrm{~b}$ & $0.1528 \mathrm{~b}$ \\
$100-50$ & $361.51 \mathrm{a}$ & $15.57 \mathrm{~b}$ & $0.0097 \mathrm{~b}$ & $0.1472 \mathrm{~b}$ \\
$100-100$ & $416.11 \mathrm{a}$ & $16.31 \mathrm{~b}$ & $0.0105 \mathrm{~b}$ & $0.1613 \mathrm{~b}$ \\
\hline
\end{tabular}

A

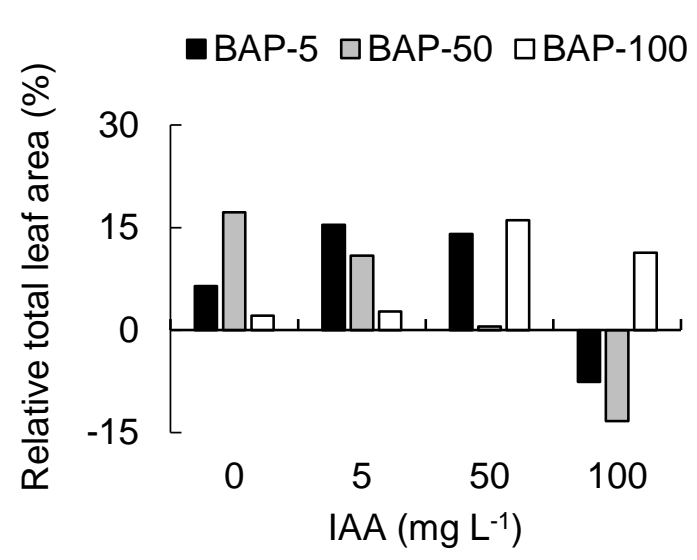

B

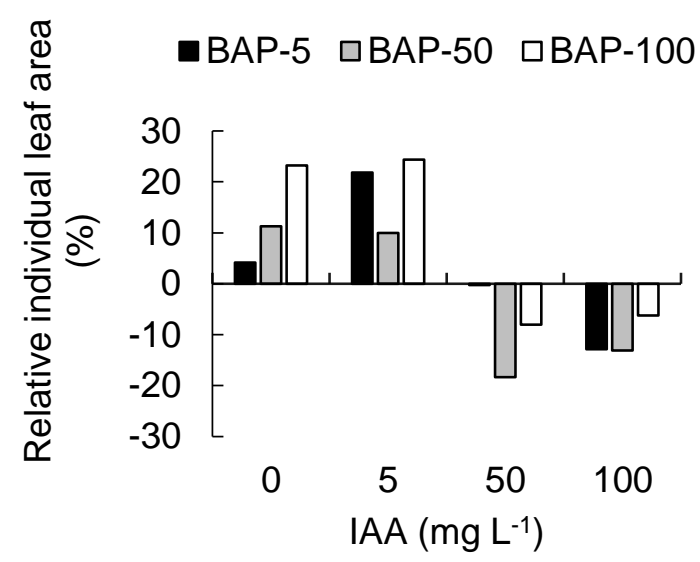


C

-BAP-5 口BAP-50 口BAP-100

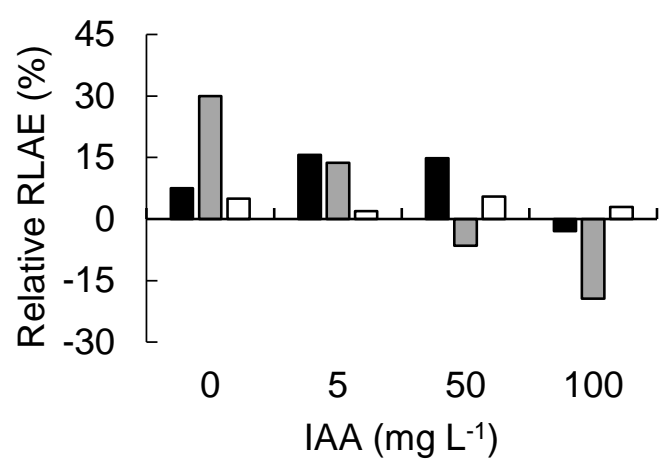

D

BAP-5 口BAP-50 口BAP-100

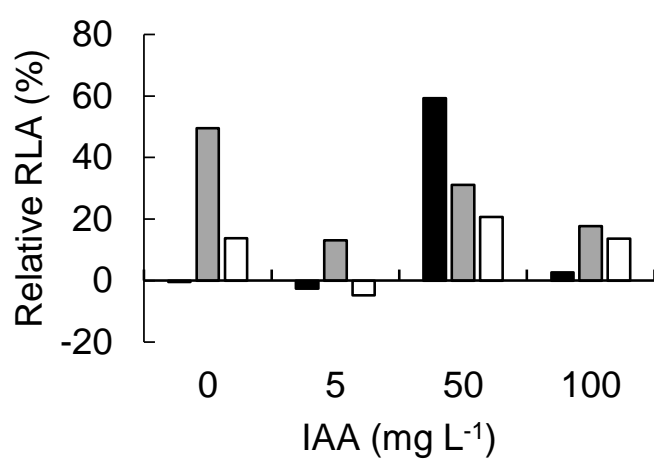

Fig. 4: The effect of a 5, 50, or $100 \mathrm{mg} \mathrm{L}^{-1}$ BAP spray application on total leaf area, individual leaf area, RLAE and RLA in plants sprayed 7 days before with IAA at $0,5,50$ or $100 \mathrm{mg} \mathrm{L}^{-1}$. Data are expressed as the percentage change observed following BAP application of 5,50 or $100 \mathrm{mg} \mathrm{L}^{-1}$ relative to plants sprayed with $0 \mathrm{mg} \mathrm{L}^{-1}$ BAP.

\section{Dry weight accumulation and partitioning}

1. hawkeri plants IAA and BAP single or sequentially sprayed showed significant DW differences with control ones as a result of both shoots and roots DW increase (Fig. 5A). In plants treated with IAA and, 7 days later with BAP, addition of the second hormone resulted in only a slight growth promoting effect (near 20\%), which tended to be lower with increasing IAA and BAP concentrations (Fig. 5B). A positive relationship between root DW and shoot DW was found when all recorded DW data were plotted in Fig. $5 \mathrm{C}$.

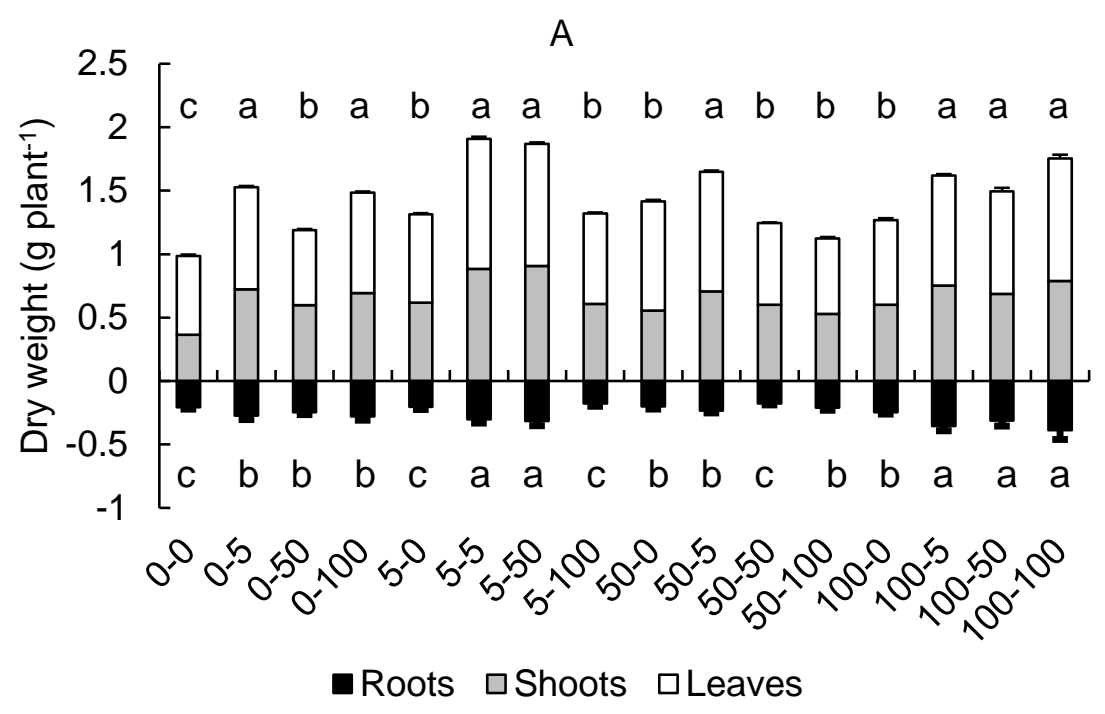


B

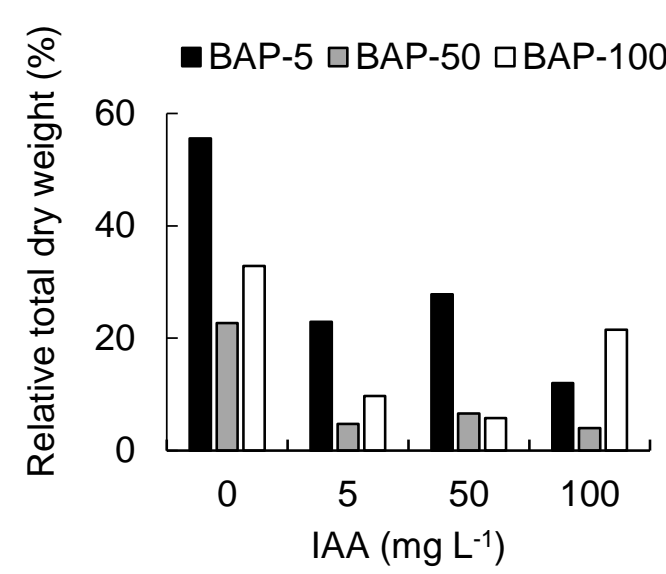

C

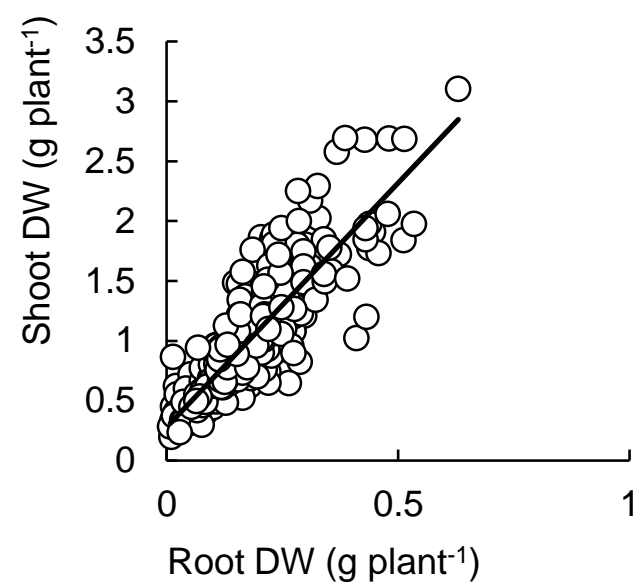

Fig. 5: Roots, shoots and leaves DWs at the end of the experiment 2 of $I$. hawkeri plants sprayed with different IAA-BAP combinations (A). Panel B shows the effect of a 5, 50, or $100 \mathrm{mg} \mathrm{L}^{-1}$ BAP spray application on relative total DW in plants sprayed 7 days before with IAA at $0,5,50$ or $100 \mathrm{mg} \mathrm{L}^{-1}$. Data are expressed as the percentage change observed following BAP application of 5,50 or $100 \mathrm{mg} \mathrm{L}^{-1}$ relative to plants sprayed with $0 \mathrm{mg} \mathrm{L}^{-1}$ BAP. Panel C indicated root: shoot DW relationships.

Table 4: Changes in RGR, NAR, LAR and $\beta$ partition coefficient at the end of experiment 2 of $I$. hawkeri plants sprayed with different IAA-BAP combinations. The probability of the slope being zero was $P \leq 0.001$ for RLAE and RLA. Different lower case letters indicate significant differences $(P \leq 0.05)$ between control and IAA-BAP sprayed plants.

\begin{tabular}{lcccc}
\hline IAA-BAP & RGR & NAR & LAR & $\beta$ \\
& \multicolumn{3}{c}{$\left(\mathrm{g} \mathrm{cm}^{-2} \mathrm{day}^{-1}\right)$} \\
$\left(\mathrm{mg} \mathrm{L}^{-1}\right)$ & $\left(\mathrm{g} \mathrm{g}^{-1} \mathrm{day}^{-1}\right)$ & $\left(\times 10^{-5}\right)$ & $\left(\mathrm{cm}^{2} \mathrm{~g}^{-1}\right)$ & \\
\hline $0-0$ & $0.0117 \mathrm{c}$ & $4.13 \mathrm{c}$ & $283.35 \mathrm{a}$ & $0.408 \mathrm{a}$ \\
$0-5$ & $0.0158 \mathrm{a}$ & $5.68 \mathrm{a}$ & $278.11 \mathrm{a}$ & $0.402 \mathrm{a}$ \\
$0-50$ & $0.0147 \mathrm{a}$ & $5.34 \mathrm{a}$ & $275.45 \mathrm{a}$ & $0.446 \mathrm{a}$ \\
$0-100$ & $0.0159 \mathrm{a}$ & $5.66 \mathrm{a}$ & $281.13 \mathrm{a}$ & $0.393 \mathrm{a}$ \\
$5-0$ & $0.0137 \mathrm{~b}$ & $4.97 \mathrm{~b}$ & $275.56 \mathrm{a}$ & $0.449 \mathrm{a}$ \\
$5-5$ & $0.0179 \mathrm{a}$ & $6.73 \mathrm{a}$ & $265.89 \mathrm{a}$ & $0.415 \mathrm{a}$ \\
$5-50$ & $0.0179 \mathrm{a}$ & $6.30 \mathrm{a}$ & $284.12 \mathrm{a}$ & $0.424 \mathrm{a}$ \\
$5-100$ & $0.0143 \mathrm{~b}$ & $5.18 \mathrm{a}$ & $276.00 \mathrm{a}$ & $0.437 \mathrm{a}$ \\
$50-0$ & $0.0152 \mathrm{a}$ & $5.47 \mathrm{a}$ & $277.83 \mathrm{a}$ & $0.409 \mathrm{a}$ \\
$50-5$ & $0.0166 \mathrm{a}$ & $5.99 \mathrm{a}$ & $277.02 \mathrm{a}$ & $0.347 \mathrm{~b}$
\end{tabular}




\begin{tabular}{lllll}
$50-50$ & $0.0134 \mathrm{~b}$ & $4.92 \mathrm{~b}$ & $272.60 \mathrm{a}$ & $0.323 \mathrm{~b}$ \\
$50-100$ & $0.0126 \mathrm{~b}$ & $4.56 \mathrm{~b}$ & $276.08 \mathrm{a}$ & $0.364 \mathrm{~b}$ \\
$100-0$ & $0.0134 \mathrm{~b}$ & $4.78 \mathrm{~b}$ & $280.09 \mathrm{a}$ & $0.360 \mathrm{~b}$ \\
$100-5$ & $0.0167 \mathrm{a}$ & $6.27 \mathrm{a}$ & $266.16 \mathrm{a}$ & $0.363 \mathrm{~b}$ \\
$100-50$ & $0.0157 \mathrm{a}$ & $5.72 \mathrm{a}$ & $274.71 \mathrm{a}$ & $0.311 \mathrm{~b}$ \\
$100-100$ & $0.0160 \mathrm{a}$ & $5.84 \mathrm{a}$ & $273.96 \mathrm{a}$ & $0.318 \mathrm{~b}$ \\
\hline
\end{tabular}

A

- BAP-5 口BAP-50 घBAP-100

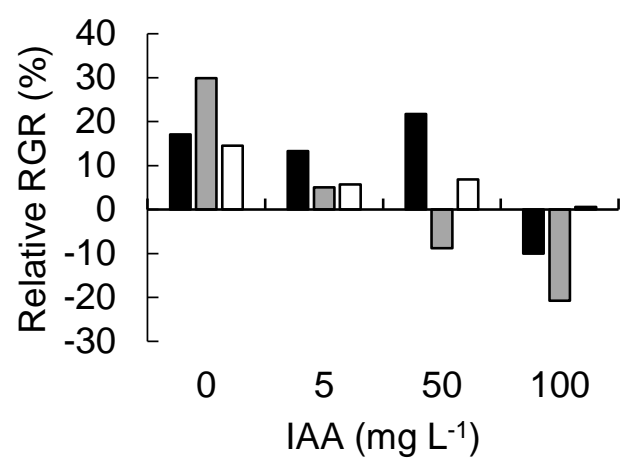

C

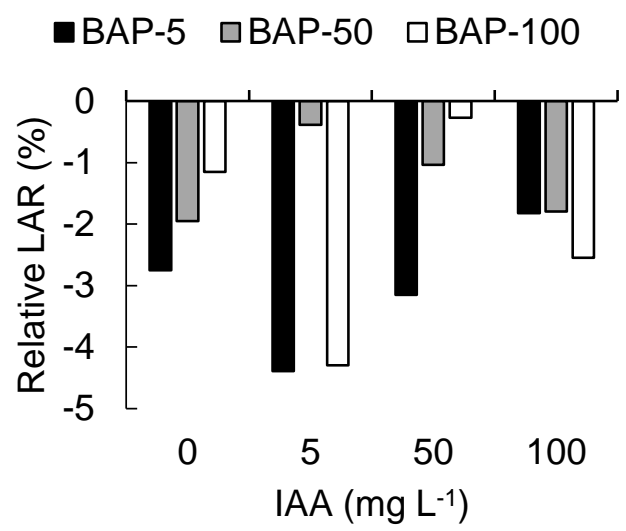

B

-BAP-5 口BAP-50 口BAP-100

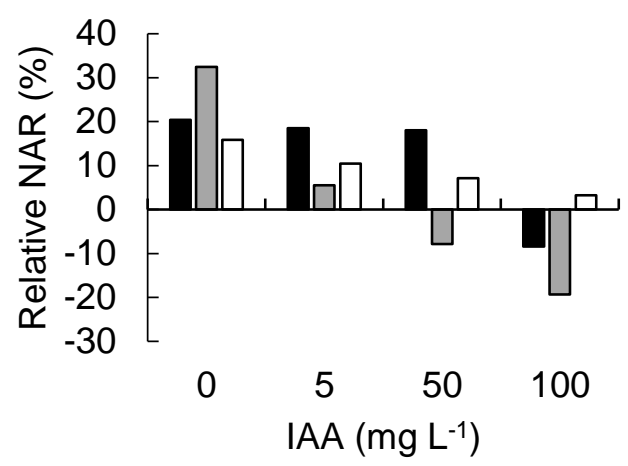

D

-BAP-5 口BAP-50 口BAP-100

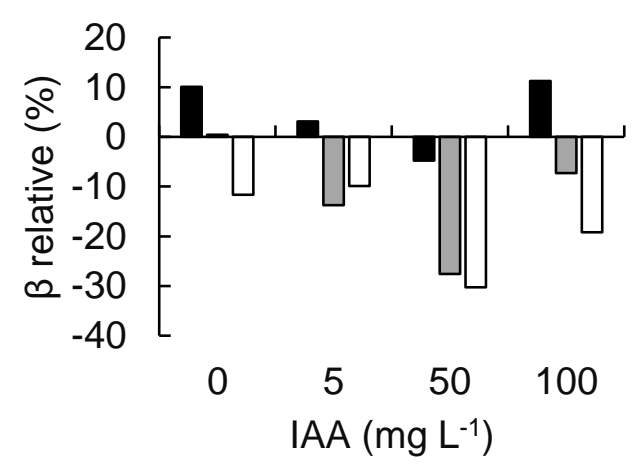

Fig. 6: The effect of a 5, 50, or $100 \mathrm{mg} \mathrm{L}^{-1}$ BAP spray application on RGR, NAR, LAR and $\beta$ partition coefficient in plants sprayed 7 days before with IAA at $0,5,50$ or $100 \mathrm{mg} \mathrm{L}^{-1}$. Data are expressed as the percentage change observed following BAP application of 5,50 or $100 \mathrm{mg} \mathrm{L}^{-1}$ relative to plants sprayed with $0 \mathrm{mg} \mathrm{L}^{-1}$ BAP. 
Plants sprayed with different IAA-BAP combinations increased RGR and NAR with only few changes in LAR when compared with control ones. The $\beta$ partition coefficient decreased as soon as IAA concentration increased to 50 and $100 \mathrm{mg} \mathrm{L}^{-1}$ (Table 4).

In plants treated with IAA and, 7 days later with BAP, addition of the second hormone resulted in a near $30 \%$ growth promoting effect for RGR (Figure 6A) and NAR (Figure 6B) with minor changes in LAR (Figure 6C). However, the $\beta$ partition coefficient showed a 30\% decrease (Figure 6D).

When plotting the data from all treatments, we found a close direct relationship $\left(r^{2}=0.977\right)$ between RGR and NAR (Figure 7A) and a weak direct relationship between RGR and LAR $\left(r^{2}=0.093\right)$ (Figure 7B). Nevertheless, controls plants showed the lower NAR values.

A

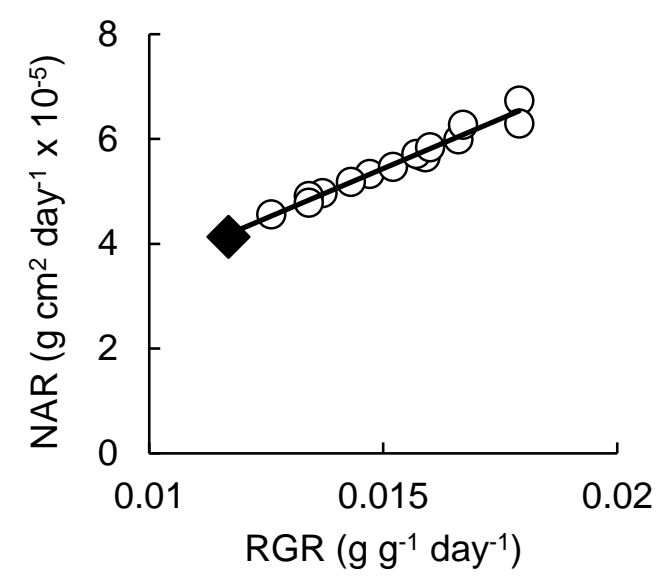

B

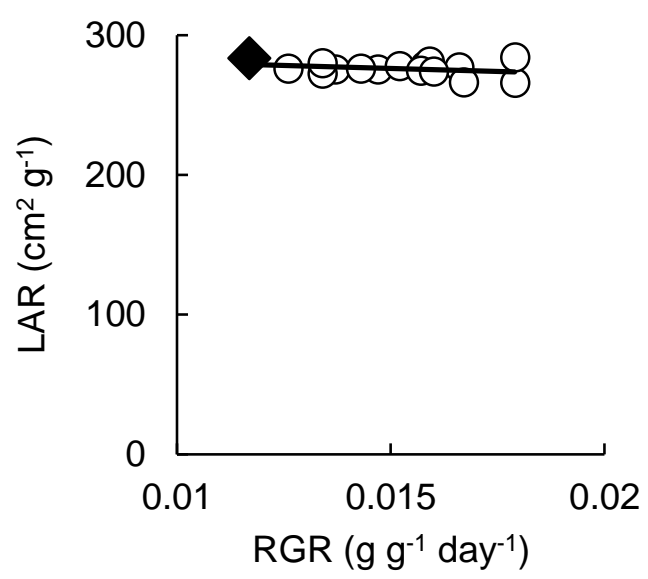

Fig. 7. The net assimilation rate (NAR) $(A)$ and the leaf area ratio $(L A R)(B)$ related to the relative growth rate (RGR). The straight-line regressions were NAR $=378.85 R G R-0.25\left(r^{2}=0.977 ; P \leq 0.001\right)$ and $L A R=857.45 R G R$ +289.07 ( $r^{2}=0.093 ; P$ no significant). Full or empty symbols indicated both controls and IAA-BAP sprayed plants respectively.

\section{Leaf anatomy}

Increases in overall leaf thickness were observed in plants sprayed with different IAA-BAP combinations (Fig. $8 A)$. A decrease in the contribution of the epidermal layer to overall leaf thickness was observed following either IAA or BAP treatment. Conversely, a significant increase in the proportion of intercellular spaces was observed, while only slight changes were seen in the proportion of the parenchymal layer (Fig. 8B). 
A

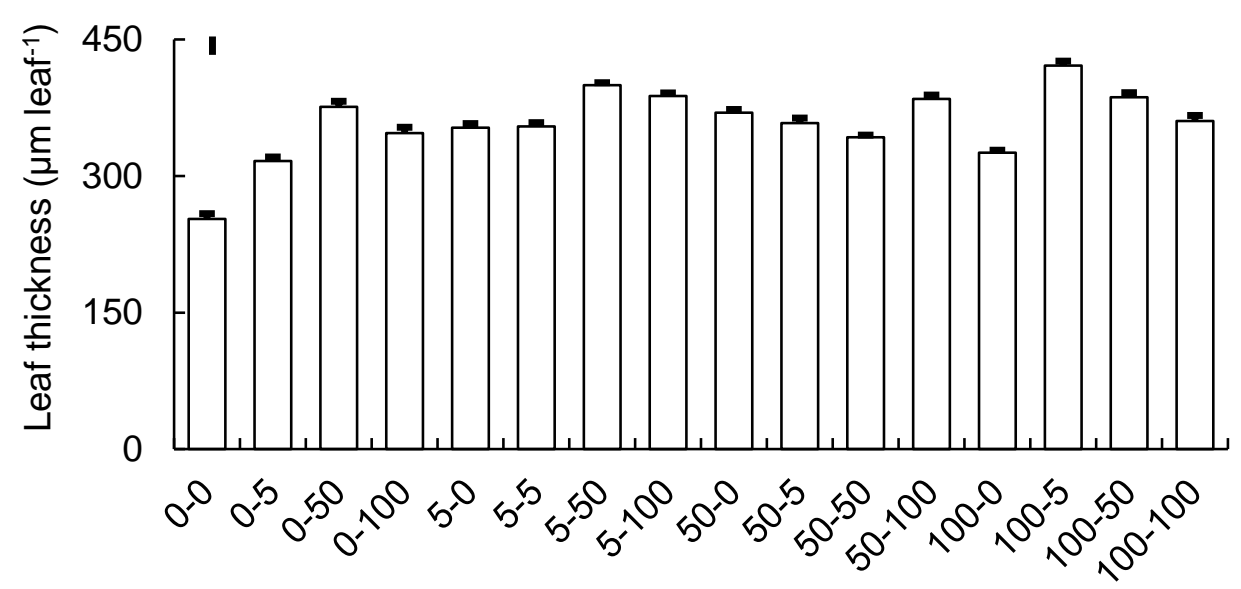

$B$

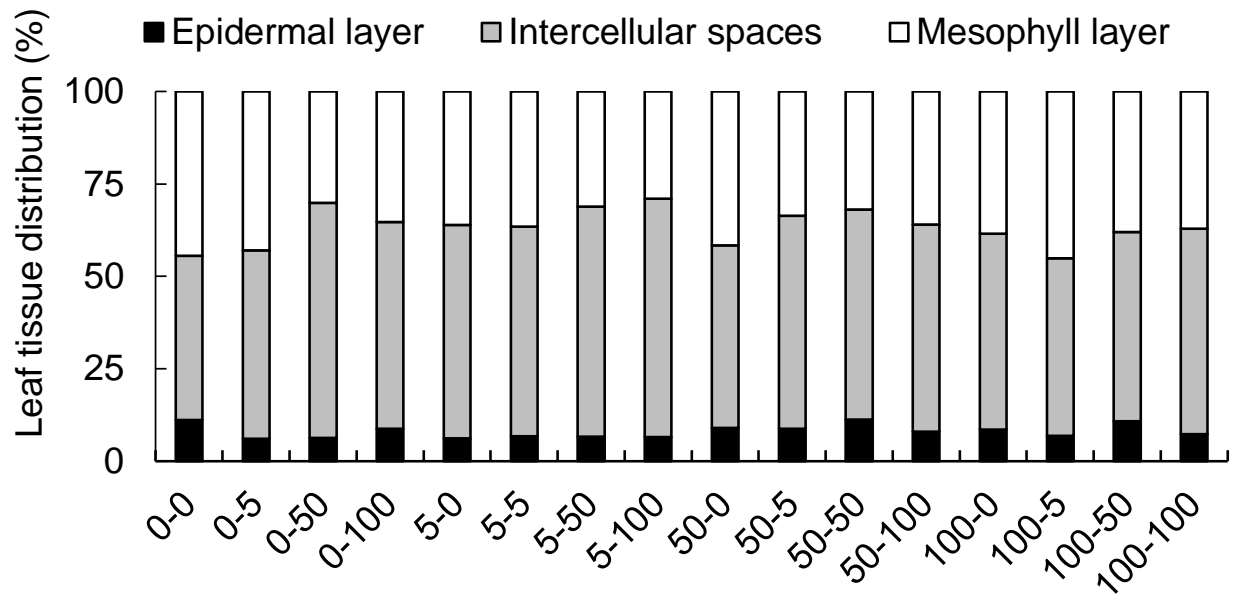

C

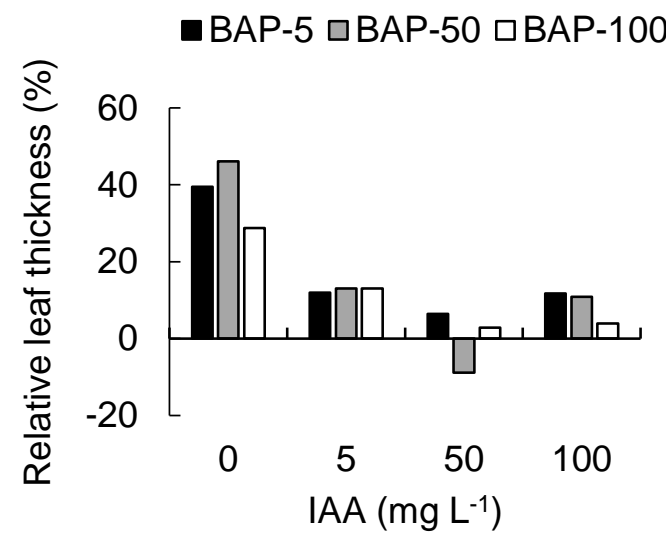

$\mathrm{D}$

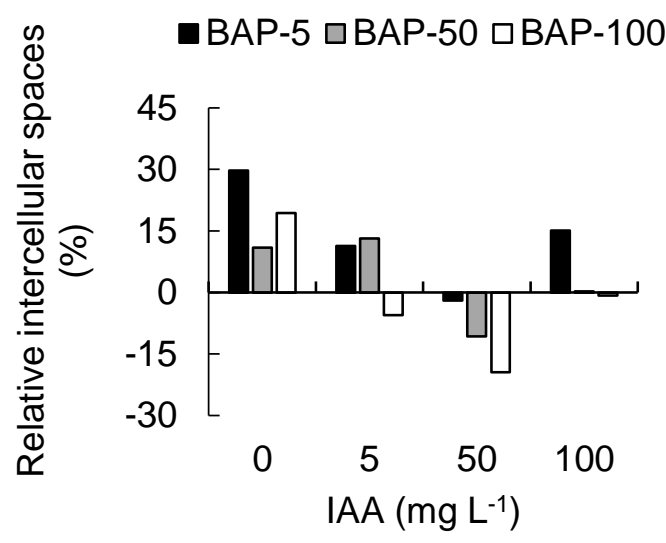

Fig. 8: Changes in leaf thickness $(A)$ and contributions (expressed as percentages) of the epidermal layer, parenchymal layer, and intercellular spaces respectively to the overall thickness (B) of leaves on I. hawkeri plants sprayed with $0,5,50$, or $100 \mathrm{mg} \mathrm{L}^{-1}$ IAA or BAP as a single or combined hormone application. Vertical lines indicate least significant differences (LSD). In panel $C$ and D plants were sprayed with IAA at 0,5, 50 or $100 \mathrm{mg}$ 
$\mathrm{L}^{-1}$. data are expressed as the percentage change observed following BAP application of 5,50 or $100 \mathrm{mg} \mathrm{L}^{-1}$ relative to plants sprayed with $0 \mathrm{mg} \mathrm{L}^{-1} \mathrm{BAP}$.

In plants treated with $5-100 \mathrm{mg} \mathrm{L}^{-1} \mathrm{IAA}$, a later application of BAP had no consistent effect on these variables (Fig. $8 \mathrm{C}$ ), although, in general, BAP contributed to a decrease the proportion of the epidermal layer, increases in the percentage of intercellular spaces were lower as the BAP concentration increased (Fig. 8D).

Positive relationships between NAR related to both leaf thickness $\left(r^{2}=0.641\right)$ (Fig. 9A) and intercellular spaces $\left(r^{2}=0.708\right)$ (Fig. 9B) when all data were plotted together. In both cases, control plans showed the lower values.

A

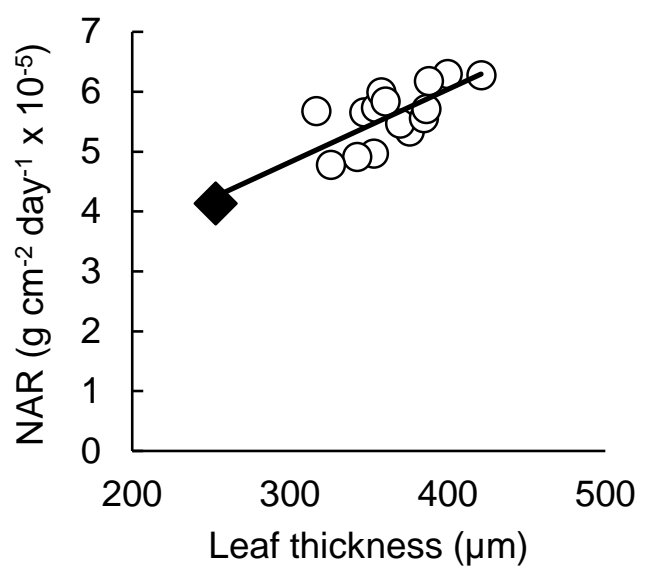

B

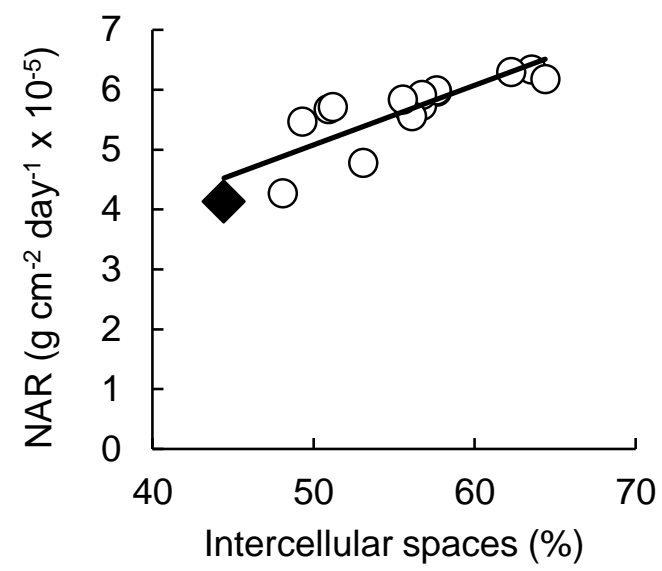

Fig. 9: The net assimilation rate (NAR) related to leaf thickness $(A)$ or the intercellular spaces (B). The straightline regressions were NAR $=0.012$ leaf thickness $+1.19\left(r^{2}=0.641 ; P \leq 0.05\right)$ and NAR $=0.100$ intercellular spaces $+0.098\left(r^{2}=0.708 ; P \leq 0.001\right)$. Full or empty symbols indicated both controls and IAA-BAP sprayed plants respectively.

\section{Growth parameters relationships}

Positive relationships between RLAE (Fig. 10A), RLA (Fig. 10B), RGR (Fig. 10C), NAR (Fig. 10D) and root DW $\left(r^{2}=\right.$ $0.691,0.700,0.644$ and 0.638 respectively) were found at the end of the experiment with the lower values belonged to control plants always. On the other hand, a negative relationship between the $\beta$ partition coefficient (Fig. 10E) and root DW $\left(r^{2}=0.546\right)$ was found. In this case, control plants showed the higher $\beta$ values.

A

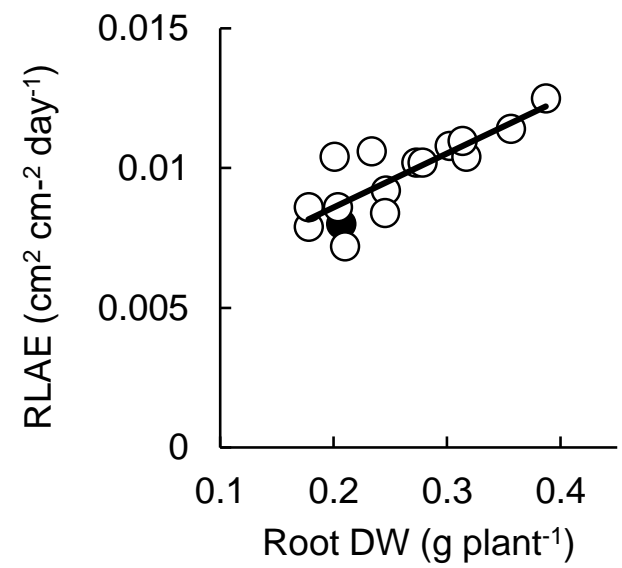

B

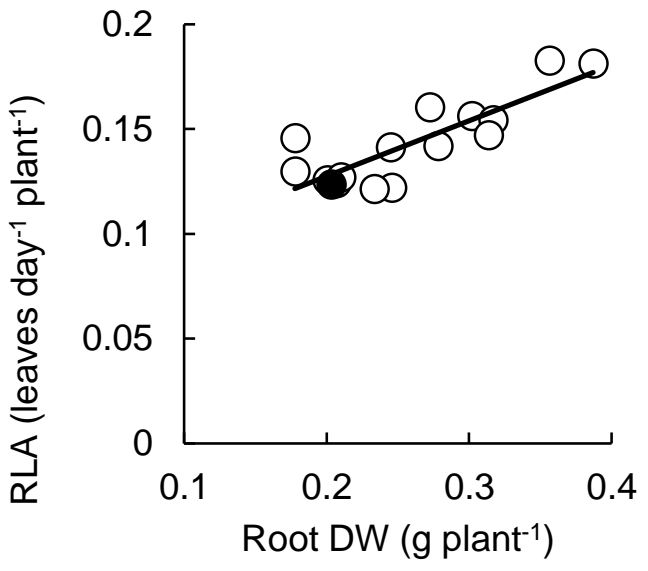


C

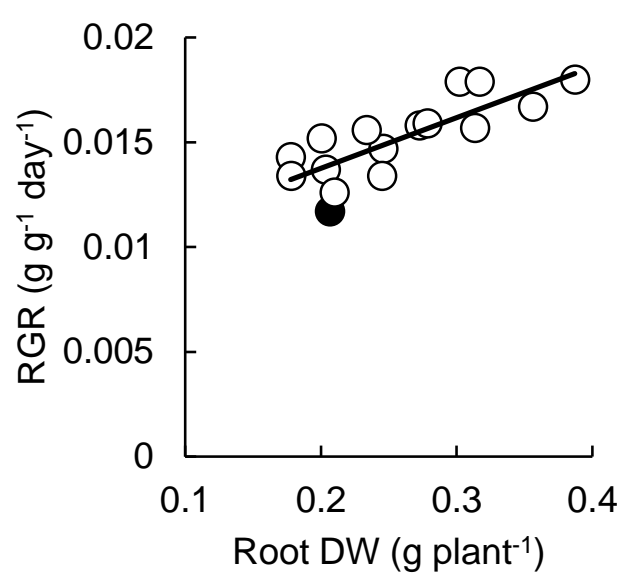

D

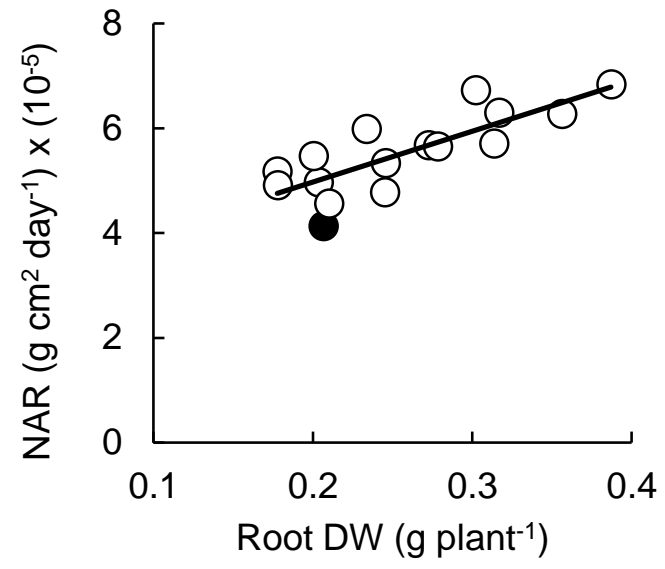

E

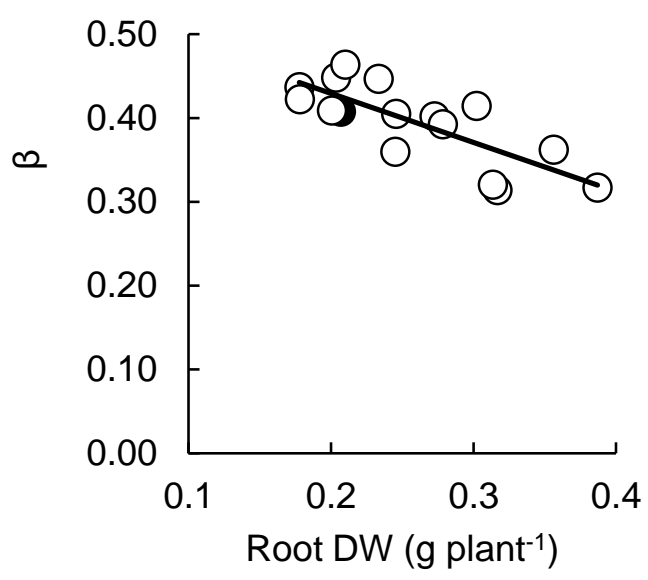

Fig. 10. The relative leaf area expansion rate (RLAE) $(A)$, the rate of leaf appearance (RLA) (B), the relative growth rate $(R G R)(C)$, the net assimilation rate $(D)$ and the partition coefficient $\beta$ (E) related to the relative root DW (RDW). The straight-line regressions were RLAE $=0.019$ RDW $-0.005\left(r^{2}=0.691 ; P \leq 0.001\right), R L A=0.265$ RDW $0.075\left(r^{2}=0.700 ; P \leq 0.001\right), R G R=0.024 R D W+0.009\left(r^{2}=0.644 ; P \leq 0.05\right), N A R=9.696 \times 10^{-5} R D W+3.03\left(r^{2}\right.$ $=0.638 ; P \leq 0.05), \beta=-0.585$ RDW $+0.546\left(r^{2}=0.606 ; P \leq 0.05\right)$. Full or empty symbols indicated both controls and IAA-BAP sprayed plants respectively.

\section{Discussion}

The productivity of ornamental plants is closely associated with an increase in their total leaf area over time, but most ornamental plants show low rates of leaf expansion (Di Benedetto et al., 2006, 2010). Although biomass accumulation on a DW base appears to be the best leaf trait to be quantified for plant functional screenings (Poorter et al., 2012), the quality of ornamental plants can be appraised with other types of criteria, such as tolerance to biotic and abiotic stresses, development potentialities and aesthetics (Santagostini et al., 2014).

During the last years, strong suggestions from our laboratory on the effect of a single BAP spray to increase vegetable (Pagani et al., 2013; Coro et al., 2014; Di Matteo et al., 2015; Della Gaspera et al., 2016; Rattin et al., 2017, 2018; Geraci et al., 2018) and ornamental (Di Benedetto and Pagani, 2013; De Lojo and Di Benedetto, 2014; Gandolfo et al., 2014; Di Benedetto et al., 2015a; De Lojo et al., 2017; Piotti et al., 2018) growth rate has been collected. Data from Figs. 1 and $3 A$ are in agreement with these previous reports. However, only recently, it has been shown that a successive IAA and BAP spray increased pre- (Molinari et al., 2018) and post-fresh weight in 
foliage ornamental plants (Di Benedetto et al., 2015b, 2018). On the other hand, under a non-limited light environment and optimal growth facilities, Fig. 3B showed that a single exogenous BAP seven days after an IAA spray increased New Guinea Impatiens fresh weight. These results are in agreement with previous reports, which indicated that the activity of a given hormone is also dependent on its interaction with other hormones (GarayArroyo et al., 2012).

Aesthetically, total leaf area is the main trait related to plant quality of ornamentals and it determines the time of plant sale. In physiological terms, it implies to expand leaf area at the higher growth rate which included both individual leaf size and leaf number. The primary shoot apical meristem is responsible for generating all above ground organs (Perilli et al., 2010) and is controlled by hormones, which regulate biosynthesis and transport of other hormones and by hormone interactions. They included auxins, cytokinins and gibberellins, which act both independently and in combination to regulate meristem function (Durbak et al., 2012, Di Benedetto et al., 2013, 2015a, b; 2018).

Leaves are formed into an initial group of cells within the meristem; one of the earliest markers for leaf initiation is the down regulation of KNOTTED and WUSCHEL genes in these cells (Moon and Hake, 2011; Holt et al., 2014). Genetic analyses have demonstrated that a high cytokinin: low gibberellin ratio is important for KNOX gene function (Hake et al., 2004; Hay and Tsiantis, 2010). Cytokinins are mainly synthesized in the roots (Kieber and Schaller, 2004) and move through the stem xylem to the shoot apical meristem, although the effective cytokinin concentration is the result of endogenous and environmental signals (Kudo et al., 2010).

The main function of endogenous cytokinins are to control the cell cycle and shoot apical meristem growth (Bögre et al., 2008; Schaller et al., 2014; Brenner and Schmulling, 2015). Cytokinin-rich tissues, such as the shoot apical meristem, are photo assimilates sinks (Francis and Halford, 2006). In agreement with these reports, our results showed that a single BAP spray (Table 1) or a combined IAA-BAP spray (Table 3 ) increased total leaf area and RLAE with a strong effect on RLA. An additive weak effect of IAA-BAP combinations in total leaf area, individual leaf area and RLAE was found. However, RLA showed a higher complementary effect.

A higher individual leaf area would be explained by the common effect of cytokinins on leaf expansion (Shani et al., 2010; Gonzalez et al., 2010; Hepworth and Lenhard, 2014). Since I. hawkeri leaves appeared on a single shoot without branches, the increase in RLA would indicate a shorter plastochron. RLA increases are related to plastochron decrease, which require a shoot apical meristem increase as well (Skylar and Wu, 2011) and the non-limiting photo assimilate supply to hold vegetative plant growth (Demura and Ye, 2010; Hao and Cui, 2012). The last, needs for a photosynthetic capacity increase and/or a change in photo assimilates partitioning (Feller et al., 2015). Tables 2 and 4 showed that single or combined IAA and BAP sprays increased NAR (a photosynthetic estimator). In the same way, as root: shoot as photo assimilates partitioning increase to shoots would justify RLA changes through to a plastochron decrease. Although Shani et al. (2010) have indicated that cytokinins can affect foliar primordium insertion in the shoot apical meristem, the change in plastochron in response to an exogenous BAP spray has only recently suggested in other vegetable and ornamental plants (Di Benedetto et al., 2013, 2018; Pagani et al., 2013; De Lojo and Di Benedetto, 2014; Coro et al., 2014; Di Matteo et al., 2015; Della Gaspera et al., 2016; De Lojo et al., 2017; Rattin et al., 2017, 2018; Geraci et al., 2018; Piotti et al., 2018; Molinari et al., 2018).

In the same way than for FW, changes in DW were found (Fig. 5A). Once again, most IAA-BAP combinations led a DW increase, although the relative effect of a second hormone was low (no more than $30 \%$ ). Anyway, a close direct relationships between shoot DW and root DW was found (Fig. 5c), in agreement with previous reports. Changes in DW would be explained through higher RGR and NAR (Tables 2 and 4) with lower effects of a second hormone spray (Figs. 6A and B). When RGR was disagreed, close direct relationships between RGR and NAR for I. hawkeri plants sprayed with different IAA-BAP combinations $\left(r^{2}=0.977\right)$ (Fig. 7A) and an inverse relationships between RGR and LAR $\left(r^{2}=0.093\right)$ (Fig. 7B) were found in agreement with previous reports (Gandolfo et al., 2014; Di Benedetto et al., 2015a; Di Matteo et al., 2015; Geraci et al., 2018), including I hawkeri (Molinari et al., 2018). 
Because Boonman et al. (2007) have indicated that cytokinins stimulate photosynthetic enzymatic expression, a relationship between photosynthetic rates and leaf anatomy has been indicated (Oguchi et al., 2003). Lightsaturated rates of photosynthesis on a leaf area basis depend not only on photosynthetic biochemistry but also on mesophyll structure. Because resistance to $\mathrm{CO}_{2}$ diffusion from the sub stomatal cavity to the stroma is substantial, it is likely that mesophyll structure affects the photosynthetic rate by affecting $\mathrm{CO}_{2}$ diffusion in the leaf (Niinemets et al., 2009, Tholen et al., 2012). Our data showed significant changes in leaf tissue distribution when sprayed with different concentrations of IAA and/or BAP prior to transplanting (Fig. 8).

In this way, Gandolfo et al. (2014) found positive relationships between leaf thickness, intercellular spaces and NAR, similar to those showed in Fig. 9A. When the mesophyll thickness of the leaf is increased, the maximum photosynthetic rate increased as well. This probably explains the strong relationship between NAR and mesophyll thickness. On the other hand, in agreement with that found by Tosens et al. (2011), we found a close positive correlation between NAR and the proportion of intercellular spaces (Fig. 9B).

Previous and present results showed that cytokinins applied to the pre-transplant stage can influence the leaf structure (Magyar-Tabori et al., 2010, Fig. 8). At the early stages of leaf development, treatment with exogenous BAP accelerates division of mesophyll cells, whereas at the later stages of development, BAP treatment activates expansion of growing cells and those, which have just accomplished their growth (Ron'zhina 2003a, b). However, the additive effect of a BAP spray after an IAA treatment would be little effect on leaf thickness (Fig. 8C) and intercellular spaces (Fig. 8D).

RGR changes would be associated with photo assimilates partitioning as well. In this way, a single BAP spray (Table 2) or a combined IAA-BAP spray (Table 4) partitioned a higher photo assimilates into shoots as was indicated by the $\beta$ coefficient decrease, with a low effect of the second hormone spray in the experiment 2 (Fig. $6)$.

Roots are able to detect the presence of their neighbor's below-ground (Puig et al., 2012; Chen et al., 2015) and respond accordingly. Cytokinins are root-synthesized, which are transported via the xylem to the shoot (Ghanem et al., 2011; Brenner and Schmülling, 2015; Hwang et al., 2012). While O'Hare and Turnbull (2004) showed that the higher the root system the higher the zeatin ribosides, it is not easy to show quantitative changes in endogenous cytokinin concentration (van Staden et al., 2008) because plants synthesize different cytokininribosides and not all have biological activity. Nevertheless, in the present study, when the root system increased, positive relationships with RLAE (Figs. 3A and 10A), RLA (Figs. 3B and 10B), RGR (Figs. 3C and 10C), NAR (Figs. $3 \mathrm{D}$ and 10D), but a negative relationship with the $\beta$ partition coefficient (Figs. 3E and 10E).

In agreement with Di Benedetto et al. (2015b) it is possible to suggest a direct effect of the exogenous cytokinins (BAP) on I. hawkeri biomass accumulation associated with a higher both primary shoot apical meristem growth and auxins synthesis. On the other hand, an exogenous auxin spray (IAA) would be an indirect effect on biomass accumulation related to a higher root meristem number and cytokinins synthesis.

\section{Conclusions}

In summary, an increase in biomass accumulation in whole-plants of $I$. hawkeri was observed as a consequence of either a single IAA or BAP spray. This was associated with an increased NAR and photo assimilates partitioning to shoots. Changes in leaf anatomy induced by either hormone (including increased overall leaf thickness, and leaf intercellular spaces) may facilitate the absorption and fixation of $\mathrm{CO}_{2}$. The similarities between the responses to either hormone, together with the lack of any IAA- BAP interaction, provide two independent routes for commercial growers to increase the productivity of this ornamental plant by using early foliar sprays. 


\section{References}

1. Ahkami, A.H.; Lischewski, S.; Haensch, K.T.; Porfirova, S.; Hofmann, J.; Rolletschek, H.; Melzer, M.; Franken, P.; Hause, B.; Druege, U.; Hajirezaei, M.R. Molecular physiology of adventitious root formation in Petunia hybrida cuttings: involvement of wound response and primary metabolism. New Phytologist, 2009, 181, 613-625.

2. Aloni, R.; Langhans, M.; Aloni, E.; Dreieicher, E.; Ullrich, C.I. Root-synthesized cytokinin in Arabidopsis is distributed in the shoot by the transpiration stream. Journal of Experimental Botany, 2005, 56, 1535-1544.

3. Bishopp, A.; Lehesranta, S.; Vatén, A.; Help, H.; El-Showk, S.; Scheres, B.; Helariutta, K.; Mähonen, A.P.; Sakakibara, H.; Helariutta, Y. Phloem-transported cytokinin regulates polar auxin transport and maintains vascular pattern in the root meristem. Current Biology, 2011, 21, 927-932.

4. Bögre, L.; Magyar, Z.; López-Juez, E. New clues to organ size control in plants. Genome Biology, 2008, 9, 226-233.

5. Boonman, A.; Prinsen, Z.; Gilmer, F.; Schurr, U.; Peeters, A.J.M.; Voesenek, L.A.C.J.; Pons, T.L. Cytokinin import rate as a signal for photosynthetic acclimation to canopy light gradients. Plant Physiology, 2007, 143, 1841 1852.

6. Brenner, W.G.; Schmülling, T. Summarizing and exploring data of a decade of cytokinin-related transcriptomics. Frontiers in Plant Science, 2015, 6, 29.

7. Chen, B.J.; During, H.J.; Vermeulen, P.J.; Kroon, H.; Poorter, H.; Anten, N.P. Corrections for rooting volume and plant size reveal negative effects of neighbour presence on root allocation in pea. Functional Ecology, 2015, 29, 1383-1391.

8. Coro, M.; Araki, A.; Rattin, J.; Miravé, P.; Di Benedetto, A. Lettuce and celery responses to both BAP and PBZ related to the plug cell volume. American Journal of Experimental Agriculture, 2014, 4, 1103-1119.

9. Currey, C.J.; Lopez, R.G. Biomass accumulation and allocation, photosynthesis, and carbohydrate status of New Guinea impatiens, geranium, and petunia cuttings are affected by photosynthetic daily light integral during root development. Journal of the American Society for Horticultural Science, 2015, 140, 542-549.

10. Della Gaspera, P.; Teruel, J.; Giardina, E.; Di Benedetto, A. Physiological and technological consequences of benzyl adenine (BAP) application on Butternut squash (Cucurbita moschata Duchesne ex Poir.) productivity. American Journal of Experimental Agriculture, 2016, 13, 1-11.

11. De Lojo, J.; Di Benedetto, A. Biomass accumulation and leaf shape can be modulated by an exogenous spray of 6-benzylaminopurine in the ornamental foliage plant Monstera deliciosa (Liebm.). Journal of Horticultural Science \& Biotechnology, 2014, 89, 136-140.

12. De Lojo, J.; Gandolfo E.; Gómez D.; Feuring V.; Monti S.; Giardina E.; Boschi C.; Di Benedetto A. Root restriction effects on the bedding pot plant Impatiens walleriana. Journal of Experimental Agriculture International, 2017, 15, 1-16.

13. Demura, T.; Ye, Z.H. Regulation of plant biomass production. Current Opinion in Plant Biology, 2010, 13, 298-303.

14. Di Benedetto, A.; Pagani, A. Dry weight accumulation in the Impatiens walleriana pot plant in responses to different pre-transplant plug cell volume. European Journal of Horticultural Science, 2013, 78, 76-85.

15. Di Benedetto, A.; Molinari, J.; Boschi, C.; Benedicto, D.; Cerrotta, M.; Cerrotta, G. Estimating crop productivity for three ornamental foliage plants. International Journal of Agricultural Research, 2006, 1, 522-533.

16. Di Benedetto, A.; Tognetti, J.; Galmarini, C. Biomass production in ornamental foliage plants: Crop productivity and mechanisms associated to exogenous cytokinin supply. The Americas Journal of Plant Science \& Biotechnology, 2010, 4, 1-22. 
17. Di Benedetto, A., Galmarini, C.; Tognetti, J. Changes in leaf size and in the rate of leaf production contribute to cytokinin-mediated growth promotion in Epipremnum aureum L. cuttings. Journal of Horticultural Science \& Biotechnology, 2013, 88, 179-186.

18. Di Benedetto, A., C. Galmarini, C.; Tognetti, J.. Exogenous cytokinin promotes Epipremnum aureum L. growth through enhanced dry weight assimilation rather than through changes in partitioning. American Journal of Experimental Agriculture, 2015a, 5, 419-434.

19. Di Benedetto, A.; Galmarini, C.; Tognetti, J. Effects of combined or single exogenous auxin and/or cytokinin applications on growth and leaf area development in Epipremnum aureum. Journal of Horticultural Science \& Biotechnology, 2015b, 90, 643-654.

20. Di Benedetto, A.; Galmarini C.; Tognetti J. New insight into how thigmomorphogenesis affects Epipremnum aureum L.: Interactions between vine training system and exogenous auxin and cytokinin action in plant development. Horticultura Brasileira, 2018, 36, 330-340.

21. Di Matteo, J.; Rattin, J.; Di Benedetto, A. Increase of spinach growth through the use of larger plug cell volume and an exogenous BAP spray. American Journal of Experimental Agriculture, 2015, 6, 372-383.

22. Durbak, A.; Yao, H.; Mc Steen, P. Hormone signaling in plant development. Current Opinion in Plant Biology, 2012, 15, 92-96.

23. Feller, C.; Favre, P.; Janka, A.; Zeeman, S.C.; Gabriel, J.P.; Reinhardt, D. Mathematical modeling of the dynamics of shoot-root interactions and resource partitioning in plant growth. PloS One, 2015, 10, e0127905.

24. Francis, D.; Halford, N.G. Nutrient sensing in plant meristems. Plant Molecular Biology, 2006, 60, 981-993.

25. Gandolfo, E.; De Lojo, J.; Gómez, D.; Pagani, A.; Molinari, J.; Di Benedetto, A. Anatomical changes involved in the response of Impatiens wallerana to different pre-transplant plug cell volumes and BAP sprays. European Journal of Horticultural Science, 2014, 79, 226-232.

26. Garay-Arroyo, A.; De La Paz Sánchez, M.; García-Ponce, B.; Azpeitia, E.; Álvarez-Buylla, E.R. Hormone symphony during root growth and development. Developmental dynamics, 2012, 241, 1867-1885.

27. Garrido, G.; Arnao, M.B.; Acosta, M.; Sánchez-Bravo, J. Polar transport of indole-3-acetic acid in relation to rooting in carnation cuttings: influence of cold storage duration and cultivar. Biologia Plantarum, 2003, 47, 481-485.

28. Geraci, J.; Di Matteo J.; Feuring V.; Giardina E.; Di Benedetto A. (Exogenous BAP spray on biomass accumulation in spinach. Journal of Experimental Agriculture International, 2018, 25, 1- 17.

29. Ghanem M.E.; Albacete, A.; Smigocki, A.C.; Frebort, I.; Pospilova, H.; Martinez-Andujar, C.; Acosta, M.; Sanchez-Bravo, J.; Lutts, S.; Dodd, I.C.; Perez-Alfocea, F. Root synthesized cytokinins improve shoot growth and fruit yield in salinized tomato (Solanum lycopersicum L.) plants. Journal of Experimental Botany, 2011, 6, 125-140.

30. Gonzalez, N., De Bodt, S.; Sulpice, R.; Jikumaru, Y.; Chae, E.; Dhondt, S.; Van Daele, T.; De Milde, L.; Weigel, D.; Kamiya, Y.; Stitt, M.; Beemster, G.T.S.; Inze, D. Increased leaf size: Different means to an end. Plant Physiology, 2010, 153, 1261-1279.

31. Hake, S.; Smith, H.M.; Holtan, H.; Magnani, E.; Mele, G.; Ramirez, J. The role of KNOX genes in plant development. Annual Review of Cell Development Biology, 2004, 20, 125-15.

32. Han, H.; Zhang, S.; Sun, X. Review on the molecular mechanism of plants rooting modulated by auxin. African Journal of Biotechnology, 2009, 8, 348-353.

33. Hao, Y.; Cui, H. SHORT-ROOT regulates vascular patterning, but not apical meristematic activity in the Arabidopsis root through cytokinin homeostasis. Plant Signaling and Behavior, 2012, 7, 314-317. 
34. Hay, A.; Tsiantis, M. KNOX genes: Versatile regulators of plant development and diversity. Development, 2010, 137, 3153-3165.

35. Hepworth, J.; Lenhard, M. Regulation of plant lateral-organ growth by modulating cell number and size. Current Opinion in Plant Biology, 2014, 17, 36-42.

36. Holt, A. L.; Van Haperen, J.M.; Groot, E.P.; Laux, T. Signaling in shoot and flower meristems of Arabidopsis thaliana. Current Opinion in Plant Biology, 2014, 17, 96-102.

37. Hutchinson, V.A.; Currey, C.J.; Lopez, R.G. Photosynthetic daily light integral during root development influences subsequent growth and development of several herbaceous annual bedding plants. HortScience, 2012, 47, 856-860.

38. Hwang, I.; Sheen, J.; Müller, B. Cytokinin signaling networks. Annual Review of Plant Biology, 2012, 63, 35380.

39. Kieber, J.J.; Schaller, G. E. Cytokinins. The Arabidopsis Book, 2014, 12, e0168.

40. [40] Klopotek, Y.; Haensch, K.T.; Hause, B.; Hajirezaei, M.R.; Druege, U. Dark exposure of petunia cuttings strongly improves adventitious root formation and enhances carbohydrate availability during rooting in the light. Journal of Plant Physiology, 2010, 167, 547-554.

41. Kudo, T.; Kiba, T.; Sakakibara, H. Metabolism and long-distance translocation of cytokinins. Journal of Integrative Plant Biology, 2010, 52, 53-60.

42. Lopez, R.G.; Runkle, E.S. Photosynthetic daily light integral during propagation influences rooting and growth of cuttings and subsequent development of New Guinea impatiens and petunia. HortScience, 2008, 43, 2052-2059.

43. Magyar-Tabori, K.; Dobranski, J.; Teixeira Da Silva, J.A.; Bulley, S.M.; Hudak, I. The role of cytokinins in shoot organogenesis in apple. Plant Cell Tissue and Organ Culture, 2010, 101, 251-267.

44. Molinari, J.; Pagani A.; Buyatti M.; Giardina E.; Di Benedetto A. Impatiens 'New Guinea' (Impatiens hawkeri Bull) propagation effects on the pre-transplant biomass accumulation. International Journal of Advances in Agriculture, 2018, 3, 1-15

45. Moon, J. \& Hake, S. How a leaf gets its shape. Current Opinion in Plant Biology, 2011, 14, 24-30.

46. Muraro, D.; Byrne, H.; King, J.; Bennett, M. The rol of auxin and cytokinin signalling in specifying the root architecture of Arabidopsis thaliana. Journal of Theoretical Biology, 2013, 317, 71-86.

47. Niinemets, U, Wright, I.J.; Evans, J.R. Leaf mesophyll diffusion conductance in 35 Australian sclerophylls covering a broad range of foliage structural and physiological variation. Journal of Experimental Botany, $2009,60,2433-2449$.

48. Oguchi, R.; Hikosaka, K.; Hirose, T. Does the photosynthetic light-acclimation need change in leaf anatomy? Plant, Cell and Environment, 2003, 26, 505-512.

49. O'Hare, T.J.; Turnbull, C.G.N. Root growth, cytokinin and shoot dormancy in lychee (Litchi chinensis Sonn.). Scientia Horticulturae, 2004, 102, 257-266.

50. Pagani, A.; Molinari, J.; Di Benedetto, A. BAP spray and plastic container responses on Asparagus officinalis L. crown growth. Journal of Life Science, 2013, 7, 827-835.

51. Perilli, S.; Moubayidin, L.; Sabatini, S. The molecular basis of cytokinin function. Current Opinion in Plant Biology, 2010, 13, 21-26.

52. Piotti, M.; Molinari, J.; Pagani, A.; Giardina, E.; Di Benedetto A. Root restriction effects on Zantedeschia aethiopica. International Journal of Plant \& Soil Science, 2018, 23, 1-15. 
53. Poorter, H., Niklas, K. J., Reich, P. B., Oleksyn, J., Poot, P.; Mommer, L. Biomass allocation to leaves, stems and roots: meta-analyses of interspecific variation and environmental control. New Phytologist, 2012, 193, 30-50.

54. Puig J.; Pauluzzi, G.; Guiderdoni, E.; Gantet, P. Regulation of shoot and root development through mutual signaling. Molecular Plant, 2012, 5, 974-983.

55. Rattin, J., Pico Estrada O.; Giardina E.; Di Benedetto A. Nursery pre- and post-transplant effects on tomato (Solanum lycopersicum L.) growth and yield. Journal of Experimental Agriculture International, 2017, 18, 114.

56. Rattin, J.; Molinari J.; Giardina E.; Di Benedetto A. Tools for improving sweet corn yield. International Journal of Advances in Agriculture, 2018, 3, 1-14.

57. Ron'zhina, E.S. Cytokinin-regulated mesophyll cell division and expansion during development of Cucurbita pepo leaves. Russian Journal of Plant Physiology, 2003a, 50, 646-655.

58. Ron'zhina, E.S. Effect of 6-benzylaminopurine on the structure of the photosynthetic apparatus of faba bean (Vicia faba L.). Applied Biochemistry and Microbiology, 2003b, 39, 411-417.

59. Santagostini, P.; Demotes-Mainard, S.; Huché-Thélier, L.; Leduc, N.; Bertheloot, J.; Guérin, V.; Bourbeillon, J.; Sakr, S.; Boumazad, R. Assessment of the visual quality of ornamental plants: Comparison of three methodologies in the case of the rose bush. Scientia Horticulturae, 2014, 168, 17-26.

60. Schaller, G.E.; Street, I.H.; Kieber, J.J. Cytokinin and the cell cycle. Current Opinion in Plant Biology, 2014, 21, 7-15.

61. Shani, E.; Ben-Gera, H.; Shleizer-Burko, S.; Burko, Y.; Weiss, D.; Ori, N. Cytokinin regulates compound leaf development in tomato. Plant Cell, 2010, 22, 3206-3217.

62. Skylar, A.; $\mathrm{Wu}, \mathrm{X}$. Regulation of meristem size by cytokinin signaling. Journal of Integrative Plant Biology, 2011, 53, 446-454.

63. StatSoft. Electronic Statistics Textbook. Tulsa, OK, USA. 2013, http://www.statsoft.com/textbook/.

64. Strefeler, M.S.; Quené, R.J.W. Variability in Water Loss Patterns of New Guinea Impatiens Cultivars and Breeding Selections. Journal of the American Society for Horticultural Science, 1995, 120, 527-531.

65. Tabak, N.M.; Von Wettberg, E. Native and introduced jewelweeds of the Northeast. Northeastern Naturalist, 2008, 15, 159-176.

66. Tholen, D.; Boom, C.; Zhu, X.G. Opinion: Prospects for improving photosynthesis by altering leaf anatomy. Plant Science, 2012, 197, 92-101.

67. Tosens, T.; Niimets, U.; Vislap, V.; Eichelmann, H.; Diez, P.C. Developmental changes in mesophyll diffusion conductance and photosynthetic capacity under different light and water availabilities in Populus tremula: how structure constrains function. Plant Cell Environment, 2011, 35: 839-856.

68. Van Staden, J.; Zazimalova, E.; George, E.F. Plant growth regulators II: Cytokinins, their analogues and antagonists. In: George, E.F.; Hall, M.A.; De Klerk G.J. Eds., Plant Propagation by Tissue Culture Springer, 2008, The Netherlands.

69. Warton, D.I.; Duursma, R.A.; Falster, D.S.; Taskinen, S. smatr 3-an R package for estimation and inference about allometric lines. Methods in Ecology and Evolution, 2012, 3, 257-259.

\section{Acknowledgements}

This work formed part of a Master Science thesis by J. Molinari at the National University of Litoral and a bachelor thesis by P. Fujinuma at the University of Buenos Aires. It was supported by the University of Buenos Aires Science Program 2014-2017 and the University of Mar del Plata 2016-2017 Science Program. 